\title{
MONITORING OF STRESS IN POLICE HORSES
}

\author{
Lelláková, M., Pavlak, A., Florián, M., Lešková, L. \\ Takáčová, D., Kottferová, J. \\ Department of Public Veterinary Medicine and Animal Welfare \\ University of Veterinary Medicine and Pharmacy in Kosice \\ Komenského 73, 04181 Košice \\ Slovakia
}

daniela.takacova@uvlf.sk

\section{ABSTRACT}

Every year, police horses undergo police training focused on passing difficult obstacles, during which their physical and mental abilities are tested. Using a method of eye movement monitoring, specifically eye blinking and eyelid twitching, we estimated if the training of horses was stressful. The results we found suggested that the training itself, per se does not affect the welfare of police horses; as it is not stressful for them because the gradual training allows the horses to adapt to different types of work or physical activity.

Key words: cortisol; eye-blink; eye-twitch; stress

\section{INTRODUCTION}

The selection of horses for work in the police force is challenging. Horses must undergo both selection and training, before they can then be included in the service. Horses can be exposed to various stimuli during training, which may be stressful for them. Such stimuli are: sirens sound, gunshots, simulated crowd noise, barking dogs or passing obstacles through fire. The accumulation of such stress stimuli has the potential to have a significant effect on the body when compared to the action of a one single stress stimulus.

Stress in animals can be defined as a combination of psychological and biological reactions to new or threatening circumstances. In response to new unknown external stimuli, horses undergo both homeostatic and behavioural changes. Further, changes in physiological parameters may develop when an external stimulus is perceived as a potential threat to alleviate a perceived stressor. Stress can have a negative or a positive effect on the body and may help the animal to cope with routine short-term stressors.

Stress in animals can be divided into acute and chronic stress. In acute stress, a short-term stressor acts, which initiates a physiological response in the stimulation of the recovery of disturbed homeostasis. In animals, such in horses, this response can be assessed by observing their behaviour or by analysing some physiological parameters; for example, cortisol release can be considered the most 
relevant catecholamine or to examine the changes of the heart rate variability $[3,4,5,16,20,21,25]$.

Researchers have examined behavioural indicators in horses that have been subjected to multiple conditions of stress. Higher head carriage, centred alignment of the ears, increased vocalizations and increased mouth movements have been demonstrated by stress challenged horses. For that purpose, by using a combination of both behavioural and physiological measures, measuring stress responses in animals seems more reliable. Y o u n g et al. [26] have produced a new scale to classify horses' stress-related behaviour. Horses displayed an improvement in oral behaviour, flattened or pinned ears and flared nostrils associated with an increase in heart rate (HR) and salivary cortisol when horses were subjected to stressful husbandry activities, such as electric coat clipper tone, social isolation and grooming procedures $[12,13,15,24]$.

In deciding the values of stress factors in horses, several authors have expressed recent interest. These can be determined from samples of blood, saliva, or faeces. For horses, taking blood samples induces tension. The measurement results could, therefore, be distorted. Other strategies that may be included among the non-invasive alternative methods used to monitor acute stress in horses have also been reported. These strategies include changes in the amounts of blinks in the eye and twitches in the eyelid. We noticed this by watching the animals and their eye expressions, whether they were stressed by the demanding training that police horses undergo. To understand the animal and eventually enhanced health, it is important to recognize valid stress indicators $[7,9,11,14,18,22,23]$.

\section{MATERIALS AND METHODS}

Our research was carried out on 9 police horses, which underwent a demanding one-day training at the equestrian centre in Košice. The training consisted of overcoming challenging simulated events, during which the horses were exposed to the sound of sirens, gunshots, fire handling, barking dogs, waving banners, etc. The horses were 6 to 14 years old (five geldings and four mares). Those horses had more than 3 years of experience with police training and they were in good physical and mental conditions. The horses were transported for $450 \mathrm{~km}$ to Košice. They were housed together after arrival in the same stable until the next day, when they completed the training. Prior to training, in the morning, all 9 horses underwent right eye monitoring for 1 minute, which was recorded using a digital camera. The horses were held by a handler on a fairly loose lead $(1 \mathrm{~m})$ with just enough contact to maintain its head relatively still without restricting the movements. After completing the horses' training in the afternoon, we monitored the horses' movement of the eyes or eyelids in the same way. We played the recorded videos using a video player (in $40 \times$ slow motion) and the eye movements were evaluated by 4 independent observers who checked the number of 3 different possible movements of the eye: full blink, half blink or eyelid twitches (Table 1). The interobserver reliability was $91.5 \%$. The average number of full, half blinks and eye twitches has been documented in Table 2 .

\section{Statistical evaluation}

All our data were reported as the mean \pm SD (standard deviation). The differences between means were determined according to the paired t-test using Microsoft Excel software. By conventional criteria, difference $(\mathrm{P}<0.05)$ was considered to be statistically significant.

\section{RESULTS AND DISCUSSION}

The aim of our study was to determine whether the method of measuring the number of blinks is suitable for measuring the stress level in horses. We verified this procedure by observing the movement of the eyes and twitching of the eyes. This method is considered non-invasive, and can be used to indicate stress in horses, as well as people.

Blinking is characterized as a rapid eyelid movement that opens and closes the palpebral fissure and consists of three distinct blinks: full, half and twitches of the eye. Complete blinks are total closure with concomitant vision suppression of both eyelids, whereas incomplete closure of the eyelids is half (partial) blinks. We understand the movement of the upper eyelid through the innervation of the muscles of the levator palpebrae superioris, without the movement of the muscles of the orbicularis oculi. In humans, partial blinks based on computer terminal screens have been observed and have been used as a diagnosis for dry eye disease. In both dogs and cats, partial blinks have also been recorded $[1,2,8,10,17,19]$. 
Table 1. Ethogram of behaviours observed in horses before and after police training

\begin{tabular}{|c|c|}
\hline Behaviour & Description \\
\hline Eye- full blink & The right eye becomes momentarily but completely closed \\
\hline Eye- half blink & $\begin{array}{l}\text { The right upper lid moved toward the lower lid of the eye but does not cover } \\
\text { the eye completely }\end{array}$ \\
\hline Eyelid- twitch & $\begin{array}{l}\text { Fine fibrillary movement of the skin involving the levator palpebrae superioris } \\
\text { muscle of the upper eyelid }\end{array}$ \\
\hline
\end{tabular}

Table 2. Average number of full, half blinks and eye twitches before and after training in police horses $(n=9)$

\begin{tabular}{|c|c|c|c|c|c|c|c|c|c|}
\hline & \multicolumn{3}{|c|}{ Full eye blinks } & \multicolumn{3}{|c|}{ Half eye blinks } & \multicolumn{3}{|c|}{ Eye twitches } \\
\hline & Mean \pm SD & P-value & $\begin{array}{c}\text { Paired } \\
\text { t-test }\end{array}$ & Mean \pm SD & P-value & $\begin{array}{l}\text { Paired } \\
\text { t-test }\end{array}$ & Mean \pm SD & P-value & $\begin{array}{c}\text { Paired } \\
\text { t-test }\end{array}$ \\
\hline Before training & $9 \pm 0.737$ & NS & \multirow{2}{*}{1.111} & $13 \pm 1.155$ & NS & \multirow{2}{*}{1.111} & $2.5 \pm 0.497$ & NS & \multirow{2}{*}{0.666} \\
\hline After training & $7.5 \pm 0.628$ & NS & & $12 \pm 1.315$ & NS & & $3.0 \pm 0.146$ & NS & \\
\hline
\end{tabular}

NS-non significant

We compared our results with those of $\mathrm{Merkies}$ et al. [14], who found that a reduction in the number of full and half blinks and an increase in the number of eyelid twitches occurs if horses are exposed to a stressful situation. The number of full blinks decreases from an average of 5 to $8-9$ blinks per minute, and the number of eye twitches increases from an average of 2 twitches per minute to 6 twitches per minute in a stressful situation. We revealed that the number of full eye blinks in the police horses decreased on average from 9 blinks per minute to 7.5 blinks per minute. The number of eye twitches did not change on average (2.5 blinks per minute before training and 3 blinks per minute after training).

According to our observations, horse training was not correlated with a decrease in eye blinking and an increase in eye twitching under stress conditions. The method of measuring eye blinking and eye twitching appeared to be a suitable alternative method for monitoring the effect of stress factors in horses. According to $\mathrm{H}$ a $\mathrm{n}$ á $\mathrm{k}$ and O l e hla [6], if a certain physical load was repeated on a regular basis and increased in length, intensity or frequency gradually, then adaptation to the corresponding physical load (training) appeared to be a fundamental biological property.

\section{CONCLUSIONS}

Monitoring eye blinking and eye twitching is considered a non-invasive procedure, and compared to the techniques used to assess cortisol levels in the blood, it can be categorized as inexpensive. The drawbacks to these approaches are the time taken to analyse the outcomes and the need to build a team of individuals. We found that no signs of stress were shown based on the assessment of eye movements in horses undergoing challenging training, supporting the hypothesis that horses can adjust to this form of load by incremental training.

\section{ACKNOWLEDGEMENTS}

This study was supported by the Cultural and educational grant agency (KEGA) of the Ministry of Education, Science, Research and Sports of the Slovak Republic No 002UVLF4/2019-Modernization of education of professional ethics and improvement of fine skills of students in the veterinary profession (In Slovak).

The authors would like to thank for the willingness to contribute to the research and for cooperation to the Slovak 
Police Headquarters, the Department of Cynology and Hippology of the Slovak Police Headquarters.

\section{REFERENCES}

1. Bennett, V., Gourkow, N., Mills, D. S., 2017: Facial correlates of emotional behaviour in the domestic cat (Felis catus). Behav. Proc., 141, 342-350. DOI: 10.1016/j.beproc.2017. 03.011 .

2. Cruz, A. A. V., Garcia, D. M., Pinto, C. T., Cechetti, S. P., 2011: Spontaneous eyeblink activity. Ocul. Surf., 9, 9-41. DOI: 10.1016/S1542-0124(11)70007-6.

3. Fazio, E., Medica, P., Cravana, C., Ferlazzo, A., 2013: Cortisol response to road transport stress in calm and nervous stallions. J. Vet. Behav. Clin. Appl. Res., 8, 4, 231-237. DOI: 10. 1016/j.jveb.2012.10.010

4. Ferlazzo, A., Medica, P., Cravana, C., Fazio, E., 2012: Circulating $\beta$-endorphin, adrenocorticotropin, and cortisol concentrations of horses before and after competitive show jumping with different fence heights. J. Equine Vet. Sci., 32, 11, 740-746. DOI: 10.1016/j.jevs.2012.02.021.

5. Fowler, V., Kennedy, M., Marlin, D., 2012: A comparison of the Monty Roberts technique with a conventional UK technique for initial training of riding horses. Anthrozoos, 25, 301-321. DOI: 10.2752/175303712X13403555186217.

6. Hanák, J., Olehla, Č., 2010: Clinical physiology of horses and their training (Online in Czech). Cit. 2019-03-28. Available on Internet: \&lt; cit.vfu.cz\&gt.

7. Hovey, M. R., Davis, A., Chen, S., Godwin, P., Porr, C. A. S., 2020: Evaluating stress in riding horses: Part one-behaviour assessment and serum cortisol. J. Equine Vet. Sci. (In press Journal pre-proof). DOI: 10.1016/j.jevs.2020.103297.

8. Jie, Y., Sella, R., Feng, J., Gomez, M. L., Afshari, N. A., 2019: Evaluation of incomplete blinking as a measurement of dry eye disease. Ocul. Surf., 17, 3, 424-433. DOI: 10.1016/j. jtos.2019.05.007.

9. Jung, A., Jung, H., Choi, Y., Colee, J., Wickens, C., Lee, J. W., Yoon, M., 2019: Frequent riding sessions daily elevate stress, blood lactic acid, and heart rate of thoroughbred riding horses. J. Vet. Behav., 32, 5, 1-5. DOI: 10.1016/j.jveb. 2019.03.012.

10. Koo Lin, L., 2013: Eyelid anatomy and function. In Holland, E. J., Mannis, M. J., Lee, W. B., (Eds.): Ocular Surface Disease: Cornea, Conjunctiva and Tear Film. Elsevier, Cambridge, UK, 11-15.
11. Krueger, K., Marr, L., Dobler, A., Palme, R., 2020: Preservation of faecal glucocorticoid metabolites and immunoglobulin A through silica gel drying from field studies in horses. Conserv. Physiol., 7, 1, 1-8. DOI: 10.1093/conphys/coz065.

12. McKinney, C., Mueller, M. K., Frank, N., 2015: Effects of therapeutic riding on measures of stress in horses. J. Equine Vet. Sci., 35, 922-928. DOI: 10.1016/j.jevs.2015.08.015.

13. Merkies, K., McKechnie, M. J., Zakrajsek, E., 2018: Behavioural and physiological responses of therapy horses to mentally traumatized humans. Appl. Anim. Behav. Sci., 205, 61-67. DOI: 10.1016/j.applanim.2018.05.019.

14. Merkies, K., Ready, Ch., Farkas, L., Hodder, A., 2019: Eye blink rates and eyelid twitches as a non-invasive measure of stress in the domestic horse. Animals, 9, 8, 562. DOI: 10.3390/ ani9080562.

15. Merkies, K., Sievers, A., Zakrajsek, E., MacGregor, H., Bergeron, R., König von Borstel, U., 2014: Preliminary results suggest an influence of psychological and physiological stress in humans on horse heart rate and behaviour. J. Vet. Behav., 9, 242-247. DOI: 10.1016/j.jveb.2014.06.003.

16. Nagel, C., Erber, R., Bergmaier, C., Wulf, M., Aurich, J., Möstl, E., Aurich, C., 2012: Cortisol and progestin release, heart rate and heart rate variability in the pregnant and postpartum mare, foetus and new-born foal. Theriogenology, 78, 4, 759-767. DOI: 10.1016/j. Theriogenology.2012.03.023.

17. Nakajima, S., Takamatsu, Y., Fukuoka, T., Omori, Y. 2011: Spontaneous blink rates of domestic dogs: A preliminary report. J. Vet. Behav., 6, 95. DOI: 10.1016/j.jveb.2010.08.015.

18. Peeters, M., Sulon, J., Serteyn, D., Vandenheede, M., 2010: Assessment of stress level in horses during competition using salivary cortisol: preliminary studies. J. Vet. Behav., 5, 4, 216-216. DOI: 10.1016/j.jveb.2009.10.043.

19. Portello, J. K., Rosenfield, M., Chu, C. A., 2013: Blink rate, incomplete blinks and computer vision syndrome. Optom. Vis. Sci., 90, 482-487. DOI: 10.1097/OPX.0b013e31828f09a7.

20. Schmidt, A., Möstl, E., Wehnert, Ch., et al., 2010a: Cortisol release and heart rate variability in horses during road transport. Horm. Behav., 57, 2, 209-215. DOI: 10.1016/j.yhbeh.2009.11.003.

21. Schmidt, A., Biau, S., Möstl, E., Becker-Birck, M., Morillon, B., Aurich, J., Faure, J. M., Aurich, C., 2010b: Changes in cortisol release and heart rate variability in sport horses during long-distance road transport. Domestic Anim. Endocrinol., 38, 3, 179-189. DOI: 10.1016/j.domaniend.2009.10.002. 
22. Strzelec, K., Kankofer, M., Pietrzak, S. 2011: Cortisol concentration in the saliva of horses subjected to different kinds of exercise. Act. Vet. B., 80, 101-105.

23. Valera, M., Bartolomé, E., Guerrero, M. J. S., et al., 2012: Changes in eye temperature and stress assessment in horses during show jumping competitions. J. Equine Vet. Sci., 32, 827-830, DOI: 10.1016/j.jevs.2012.03.005.

24. Visser, E. K., van Reenen, C. G., Hopster, H., Schilder, M. B. H., Knaap, J. H., Barneveld, A., Blokhuis, H. J., 2001: Quantifying aspects of young horses' temperament: Consistency of behavioural variables. Appl. Anim. Behav. Sci., 74, 241-258. DOI: 10.1016/S0168-1591(01)00177-0.
25. Von Lewinski, M., Biau, S., Erber, R., et al., 2013: Cortisol release, heart rate and heart rate variability in the horse and its rider: different responses to training and performance. Vet. J., 197, 2, 229-232. DOI: 10.1016 /j.tvjl. 2012.12.025.

26. Young, T., Creighton, E., Smith, T., Hosie, C., 2012: A novel scale of behavioural indicators of stress for use with domestic horses. Appl. Anim. Behav. Sci., 140, 33-43. DOI: 10.1016/j. applanim.2012.05.008.

Received November 25, 2020

Accepted January 27, 2021 